Eirini ARTEMI*

\title{
THE KNOWLEDGE OF THE TRIUNE GOD ACCORDING TO ISIDORE OF PELUSIUM
}

\section{The Triune God. One God in Trinity and Three Persons in one God.} The Trinitarian teaching is the central doctrine of the Christian religion. The Christians believe in one God who has three persons. The truth that in the unity of the Godhead there are Three Persons, the Father, the Son, and the Holy Spirit, these Three Persons being truly distinct one from another. Our faith in the Triune God is not a man-made discovery, but revelation from God. He who is unapproachable for man, reveals Himself to man and becomes approachable.

Isidore of Pelusium strongly underlines that, the hypostases of the three Persons of God are equal, because "one being a substance of the divine Trinity"1. The Triune God is known "in their own hypostases"2. The divine nature doesn't exist outside the hypostases of the Holy Trinity, nor vice versa, and they do not exist without the knowledge at their own nature. The revelation of the three divine Persons of the Triune God, each person is a perfect God, refutes the heretical beliefs of Montanus and of Sabellius. Montanus claimed that he was the organ of the Paraclete ${ }^{3}$. Also, Sabelius taught that there is one God in three hypostases but a "triprosopos Hypostasis", so he negated the existence of the three divine persons ${ }^{4}$. Isidore wants to exercise controversy to the remaining of supporters of various sects, such as the Arians, Sabellians, Apollinaristes and several others. He points out that the essence of the Godhead is one and the three persons of the Holy Trinity have the same essence, but the hypostasis is something different, and every person has the divine own substance . It is therefore a big mistake if someone refers to "the shrinkage of

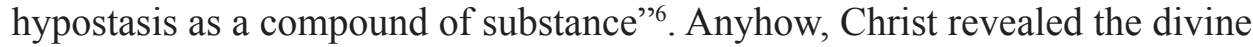

* Eirini Artemi - Theologist \& Classical Philologist, MA \& Ph.D. of Theology of National and Capodistrian University of Athens, email: eartemi@theol.uoa.gr.

${ }^{1}$ Isidorus Pelusiota, Epistula I 59 (Gorgonio), PG 78, 220C.

${ }^{2}$ Idem, Epistula I 67 (Timotheo Lectori), PG 78, 228A.

${ }^{3}$ Cf. idem, Epistula I 243 (Hermino Comiti), PG 78, 332A-B.

${ }^{4}$ Cf. idem, Epistula I 247 (Hermino Comiti), PG 78, 332D.

${ }^{5}$ Cf. idem, Epistula I 247 (Hermino Comiti), PG 78, 332D - 333A; C. Fouskas, Isidore's of Pelusium Theology, Athens 1967, 12.

${ }^{6}$ Isidorus Palusiota, Epistula I, 247 (Hermino Comiti), PG 78, 332D. 
truths and He defined "in name of the divine Trinity it is pointing out that the word substance would mean the union"?

The Pelusiote writes that God is not only the Father, as the Jews supports, but the Triune God is the three consubstantial Persons. The Triune God can be understood only if "He expands in three Persons and He «shrinks" in one God as far as the ov $\sigma^{\prime} \alpha$ - nature"8. The doctrine of the Holy Trinity, the saint Father notes, is spread out through the Old Testament ${ }^{9}$ and it was used even by Philo. The latter attempted to do a sort of "spiritual interpretation" of the Old Testament in his works ${ }^{10}$.

Isidore is of the opinion to distinguish nature and hypostasis to the Triune God, so he justifies the existence of the singular in the Bible when he refers to God: "and the Lord rained down burning asphalt from the skies" Lord, our God, is one Lord" "2. Already in the Old Testament the Triune God appears as the Creator of man and the entire world. He is created not by the Father alone, but from the Father through the Son and is perfected "in the Holy Spirit", with one will and one energy. "In the beginning God created the Heaven and the earth [...] and the spirit of God was moving over the face of the water", the Old Testament tells us characteristically, using in Hebrew the word Elohim for God, which is a plural form. At the same time, he explains when in the Bible, instead of the singular plural is used, the reference is made to hypostases of Godhead ${ }^{13}$ : "And God said, Let us make man in our image, after our likeness"14. This phrase, which comes from that passage of man's creation, reveals the existence of the three persons of God. The plural of the phrase "let us make" is not considered as plural form of politeness, but it shows the identity of the will and energy of hypostases. At the same time, the phrase is filled with the singular form of the phrase "in the image" of God, states the substance identity of the persons of the Triune God. The meaning of "in our image" (imago Dei) refers to the "inner man" because God is unformed, indestructible and intangible. It involves the rationality which the Creator gave as dowry to the spiritual nature of man and its necessary complement, the independent element of the human nature, with which the human is a moral personality, susceptible of any progress and that the man may become a "partaker of the divine nature".

Any suspicion of many Gods' existence or about being a person to God in Jewish conception is rebutted because "While the identity of nature is divided into hypostases and the property of concluded". Any suspicion of many

${ }^{7}$ Idem, Epistula I 20 (Hieraci Clarissimo), PG 78, 196A.

${ }^{8}$ Idem, Epistula II 142 (Paulo), PG 78, 585A. Cf. idem Epistula III 27 (Agatho Presbytero), PG 78, 748D - 749A.

${ }^{9}$ Cf. idem, Epistula II 143 (Paulo), PG 78, 585B.

${ }^{10} \mathrm{Cf}$. ibidem, PG 78, 585B-C.

${ }^{11}$ Idem, Epistula III 112 (Alypio), PG 78, 817C (cf. Gen 19, 24).

${ }^{12}$ Ibidem (cf. Deut 6, 4).

${ }^{13} \mathrm{Cf}$. ibidem, $\mathrm{PG} 78,817 \mathrm{~A}$.

${ }^{14}$ Ibidem, PG 78, 817C (cf. Gen 1, 26). Cf. idem, Epistula II 143 (Paulo), PG 78, 588B. 
Gods or about being a person into God in Jewish conception is rebutted because "While the identity of nature into hypostases is divided, and the property

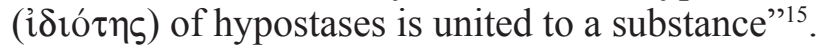

Compelling argument on which the above view is corroborated, they are the God's word: "there is no God but me: I am the Lord, and there is no other" ${ }^{\prime 16}$. With these words, God reveals the common substance between the divine persons, and, at the same time, He stresses that there is no hierarchy or series between the divine existences, because God is superior to numbers and to times ${ }^{17}$. The Holy Father drew the conclusion that "The first and second number or the first and the second series have no place on the venerable and royal Trinity"18. In another letter, he returns to toggle the use between singular and plural number, thus underlining the consubstantial divine Persons, namely the identity of nature and at the same time the distinction of hypostases: "Those, which exceed the singular number in the Holy Scriptures, express the difference of hypostases but the singular number expresses the identity of nature" 19 . He notes with emphasis that we sometimes refer to God with singular or with plural number. This breaks down the various teaching of heretics, like Sabellius, of Arius, Eunomius of the oldest prevailing views about God., such as the absolute monotheism of the Jews or the crowded pantheon of the pagans, here Isidore means mainly the religious views of the ancient Greeks and Romans ${ }^{20}$. It is worth mentioning that Isidore specifically names those heretics who troubled the congregation of the Church with their teaching in the order that they appeared on the scene of history. Thereby indirectly he shows that he is aware of the church history as well as of the role that the heretics they had played to their day.

God is one and at the same time Trinity because, "if the divinity divided into

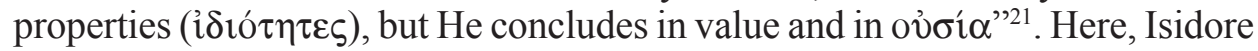

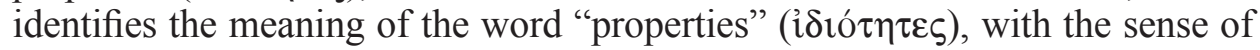
the term existence (ov $\sigma i \alpha$ ). He underlines that God is One and the Persons have the same power (o $\left.\rho_{0 \delta \delta} v \alpha \mu \alpha\right)$, consubstantial and equal among them. While, therefore, the deity is distinguished in hypostases, but he does not cease to be a God, because the hypostases are united in substance, and they have the same "value", so there is one God with three consubstantial and eternal persons ${ }^{22}$.

\footnotetext{
${ }^{15}$ Idem, Epistula III 112 (Alypio), PG 78, 817B.

${ }^{16}$ Ibidem (cf. Is 45, 6).

${ }^{17}$ Cf. idem, Epistula III 63 (Theopompo), PG 78, 772D; idem, Epistula III 18 (Agatho Presbytero), PG 78, 744D - 745A.

${ }^{18}$ Idem, Epistula III 18 (Agatho Presbytero), PG 78, 744D. Cf. idem Epistula III 63 (Theopompo), PG 78, 772D.

${ }^{19}$ Idem, Epistula III 27 (Agatho Presbytero), PG 78, 748D.

${ }^{20}$ Cf. ibidem PG 78, 748D - 749A.

${ }^{21}$ Idem, Epistula III 149 (Eutonio Diacono), PG 78, 841B.

${ }^{22} \mathrm{Cf}$. ibidem: "The divinity is widen in hypostases and He concluded in the substance and his value follows"; idem, Epistula II 143 (Paulo), PG 78, 589B.
} 
God is a plurality in unity. The unity of nature, the same substance of the Per-

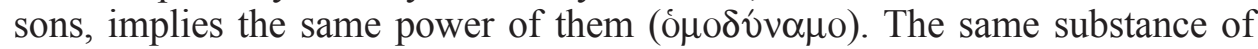
the Persons is the base for the unitary and the simplicity ( $\alpha \sigma v v \theta \varepsilon \tau 0$ ) of God. Isidore pointed out, finally, and for once again, that the things refer to the Triune God should not be delivered in silence or be forgotten by the Christians. By this he pointed how momentous is ultimately the truth of theology.

\section{The nature and the acts of the Triune God according to Isidore's of} Pelusiote teaching. There are numerous passages in the work of Isidore that teach that God, the Father, God, the Son, and God, the Holy Spirit are distinct persons and yet each hold the attributes of deity. The orthodox Christian theology has always affirmed that the one true God is triune in nature - three co-equal, co-eternal and consubstantial persons in the Godhead. Isidore underlined that the divine nature is eternal and immortal. He observed: "in God the eternity means that God is always and with no beginning" ${ }^{\prime 23}$ and he added that the properties of immortality, which is attributed to God differ from those which attached to created beings. "These beings as the angels and the soul are better than the others which were created in spoilage"24. Isidore insists that it is important for Christians and generally for people to have constantly in mind that when they speak for God, they use words from the finite human vocabulary, because "the divine is above any number, any time highest of any concept" 25 . Nothing, therefore, is so special feature for God "as the eternal" 26 . Therefore, His infinity is not subject to any alteration, development and progress which characterize only the creation and not the Creator ${ }^{27}$ :

"God is without beginning, without end, eternal and everlasting, uncreate, unchangeable, invariable, simple, uncompound, incorporeal. He cannot have any good or bad change in His nature, For I, the Lord, do not change, but although $\mathrm{He}$ is unchangeable, He has the power to improve and to put in a better situation anyone who prays to God"28.

The divine nature who is without beginning, without end, infinite, eternal and everlasting, uncreate and unchangeable ${ }^{29}$ is beyond time and place. For this reason we should not seek to know "how" the Godhead actives, because $\mathrm{He}$ is omnipotent as God and acts "well and in order to give hope to human being" ${ }^{30}$. The divine nature is "light being interceptor" 31 is considered, Isidore

\footnotetext{
${ }^{23}$ Idem, Epistula III 149 (Eutonio Diacono), PG 78, 841B.

${ }^{24}$ Ibidem.

${ }^{25}$ Ibidem.

${ }^{26}$ Idem, Epistula III, 18 (Eutonio Diacono), PG 78, 744C.

${ }^{27}$ Cf. idem, Epistula V 349 (Jacobo Lectori), PG 78, 1541C - 1544A.

${ }^{28}$ Ibidem (cf. Mal 3, 6).

${ }^{29}$ Cf. idem, Epistula IV 124 (Aigyptio Presbytero), PG 78, 1197B.

${ }^{30}$ Idem, Epistula IV 183 (Paulo Diacono), PG 78, 1276A.

${ }^{31}$ Idem, Epistula I 248 (Dracontio Presbytero), PG 78, 333A.
} 
said again, infinite, without beginning, and without end ${ }^{32}$. God's nature resembles eternal light which illuminates and brightens humanity ${ }^{33}$. The eternity of the divine nature is synonymous here with immortality ${ }^{34}$. Thus, Isidore characterized the divine nature as immortal and showed their difference between Creator and creature.

God then is infinite and incomprehensible and all that is comprehensible about Him is His infinity and incomprehensibility. But all that we can affirm concerning God does not show forth God's nature, but only the qualities of His nature ${ }^{35}$. The deity should be accepted only by his existence and his actions. Also, no one should make the slightest effort to investigate the essence of $\mathrm{God}^{36}$. This is impossible either to humans no to angels. The discourse of the essence of God is "unachievable and without any manner pregnable" ${ }^{37}$. Here Isidore had been influenced by John's Chrysostom work. "The nature of God is incomprehensible, according to Chrysostom, not only His ov̉ $\sigma i \alpha$ (substance) alone, but his wisdom also is incomprehensible even to the prophets. He is not to be compared even to the supernal virtues or to anything else; it is crime and folly to presume curiously to explore his nature; he is incomprehensible even to the angels, and so forth" 38 . The discourse of God's essence "unachievable and with no way pregnable" 39 . The dominant view about God is His description as "Lord and Creator and Superintendent and He who knows beforehand the things and guardians" ${ }^{40}$. Our faith for God must be demonstrated in practice by our works, otherwise it has no value to $\mathrm{God}^{41}$.

The divine nature is often likened to fire: "For our God is a consuming fire" ${ }^{42}$, because the fire scatters much light around it and cleaned everything that will come to her way. Fire is the basis of material and technical Culture and protects humans from the incursions of wild animals. Similar to fire the divine nature illuminates with heavenly light the souls of all those who fight for the purity in their lives. God makes these people like stars, which they have no own

\footnotetext{
${ }^{32}$ Cf. ibidem.

${ }^{33} \mathrm{Cf}$. bidem.

${ }^{34}$ Cf. idem, Epistula III 63 (Theopompo), PG 78, 772D.

${ }^{35} \mathrm{Cf}$. idem, Epistula III 214 (Lampetio Episcopo), PG 78, 893C.

${ }^{36} \mathrm{Cf}$. ibidem.

${ }^{37}$ Ibidem.

${ }^{38}$ Joannes Chrysostomus, De incomprehensibili Dei natura II 3, PG 48, 714A-B.

${ }^{39}$ Isidorus Pelusiota, Epistula II 299 (Theodosio Scholastico), PG 78, 725D.

${ }^{40}$ Ibidem.
}

${ }^{41}$ Cf. idem, Epistula III 158 (Casio Magistratum Gerenti), PG 78, 853B. Cf. Is 19, 23: "Wherefore the Lord said, Forasmuch as this people draw near me with their mouth, and with their lips do honour me, but have removed their heart far from me, and their fear toward me is taught by the precept of men" and Mt 15, 8-9: "This people draweth nigh unto me with their mouth, and honoureth me with their lips; but their heart is far from me. But in vain they do worship me, teaching for doctrines the commandments of men" (Biblical texts are cited according to the King James Bible).

${ }^{42}$ Idem, Epistula I 2 (Dorotheo Monacho), PG 78, 181 A (cf. Deut 4, 24; Heb 12, 29). 
light, but they manage to make the world bright. God prevents people's souls from Satan's arrows. The divine nature becomes the foundation for building a better world that will be the antechamber of the Kingdom of Heaven.

The pride is foreign to the divine nature. Although God could be bragging compared with all logic creatures, visible and invisible, because $\mathrm{He}$ is the creator of all creation, the absolute master of the whole universe, "the supervisor on the earth" 43 He makes the earth to shake, "He looketh on the earth, and it trembleth" 44 and $\mathrm{He}$ is superior to everyone and everything ${ }^{45}$. Through the making of creation someone can see and realize the omnipotence of God.

He created the angels, "But I the Lord, your God, founded the heaven and built the earth, whose hands built the entire army of angels in the heaven" 46 , water and nebula, "and the water above the heavens praises the name of the Lord, that he said and it became"47. He placed the clouds as a garment around the $\operatorname{sea}^{48}$. He created animals, and with wisdom He equipped them all, in order to continue to perpetuate their species ${ }^{49}$. Finally, on top of creature, God put the $\operatorname{man}^{50}$ and made him king ${ }^{51}$ and ruler of nature ${ }^{52}$. So God created man in his own image, in the image of God created he him, in order to become with his option equal to God. So the exhortation of Christ put into practice: "To become similar to your Father in heaven", because the creature ensures "in the image" and the option the "likeness of itself" 53 .

The three persons of the Holy Trinity "anointed" man as king of all creation, which is work of their hands, "With glory and honor You, God, crowned him and You make him to rule over the works of Your hands" 54 As it be mentioned above, God made man "in His image and His likeness", providing him the opportunity and the power, so he can freely choose the virtue, in order to be equal to God, man's creator ${ }^{55}$. The Triune God as omnipotent and creator, knows the most innermost thoughts of his creation, of his creature and sees in his heart, "God knows the human heart, because He is the only creator of hearts" 56 . The God does not deprive any man to have the opportunity to put into practice his thoughts, otherwise the God would deprive from His perfect creature the ability

\footnotetext{
${ }^{43}$ Idem, Epistula I 99 (Gelasio Duci), PG 78, 249C.

${ }^{44}$ Idem, Epistula IV 107 (Theodosio), PG 78, 1173A (cf. Ps 103, 32).

${ }^{45}$ Cf. idem, Epistula V 506 (Alypio), PG 78, 1617B.

${ }^{46}$ Idem, Epistula I 343 (Silvano), PG 78, 380A (cf. Hos 13, 4).

${ }^{47}$ Ibidem, (cf. Ps 148, 4).

${ }^{48}$ Cf. ibidem (cf. Job 38, 9).

${ }^{49}$ Cf. idem, Epistula II 119 (Ophelio Grammatico), PG 78, 560B.

${ }^{50}$ Cf. idem, Epistula III 95 (Isidoro Diacono), PG 78, 804A.

${ }^{51} \mathrm{Cf}$. idem, Epistula II 115 (Dorotheo), PG 78, 556C.

${ }^{52}$ Cf. idem, Epistula III 208 (Petro Monacho), PG 78, 889C-D.

${ }^{53}$ Idem, Epistula III 95 (Isidoro Diacono), PG 78, 804A (cf. Mt 5, 48).

${ }^{54}$ Ibidem, PG 78, 801C (cf. Ps 8, 6-7).

${ }^{55} \mathrm{Cf}$. idem (cf. Gen 1, 26).

${ }^{56}$ Idem, Epistula I 17 (Paulo), PG 78, 192A.
} 
of choice. Moreover the three Persons of God endowed man with an immortal soul, "which is not consubstantial with pre-eternal, no beginning and creative holly nature" 57 . The adjective immortal for human soul is misused, because, once, the soul was created and did not pre-exist. On the other hand the term immortal is taken literally meaning only for the eternal and pre-existing God.

Isidore underlines that the Triune God exists "beyond" of the world and therefore the human being fails to know Him through his own forces. God reveals His idioms but He never reveals His ov̉oí $\alpha$ - nature. Isidore urges that the deity should be accepted only by His existence and actions, and the human should not make any effort to investigated God's substance, because it is impossible for people and for the heavenly hosts too. Isidore teaches that the Immaculate and ineffable divine nature is far from any time and place, so there is no significance into the numeric "order" of the persons of the Trinity.

3. Epiphany - Revelation of the God Father. The word "epiphany"

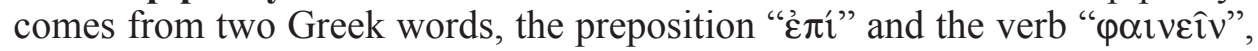
and can variously mean, "to shine upon", "to reveal", or "to appear, manifest". In the Old Testament, there are crowd of epiphanies of God Father. Sometimes, he appears as an angel ${ }^{58}$, sometimes as a fire ${ }^{59}$. There are times that the Father shows Himself with various other ways. So He makes "visible" His presence in

${ }^{57}$ Idem, Epistula V 187 (Aegypto Presbytero), ed. M.P. Évieux, SCh 454, Paris 2000, 128, line $2(=\mathrm{PG} 78,1444 \mathrm{C})$.

${ }^{58} \mathrm{Cf}$. Gen 6, 7-14: "And the angel of the Lord found her by a fountain of water in the wilderness, by the fountain in the way to Shur. And he said, Hagar, Sarai's maid, whence camest thou? and whither wilt thou go? And she said, I flee from the face of my mistress Sarai. And the angel of the Lord said unto her, Return to thy mistress, and submit thyself under her hands. And the angel of the Lord said unto her, I will multiply thy seed exceedingly, that it shall not be numbered for multitude. And the angel of the Lord said unto her, Behold, thou art with child, and shalt bear a son, and shalt call his name Ishmael; because the Lord hath heard thy affliction. And he will be a wild man; his hand will be against every man, and every man's hand against him; and he shall dwell in the presence of all his brethren. And she called the name of the LORD that spake unto her, Thou God seest me: for she said, Have I also here looked after him that seeth me? Wherefore the well was called Beerlahairoi; behold, it is between Kadesh and Bered. And Hagar bare Abram a son: and Abram called his son's name, which Hagar bare, Ishmael”; Gen 32, 24-30: „And Jacob was left alone; and there wrestled a man with him until the breaking of the day. And when he saw that he prevailed not against him, he touched the hollow of his thigh; and the hollow of Jacob's thigh was out of joint, as he wrestled with him. And he said, Let me go, for the day breaketh. And he said, I will not let thee go, except thou bless me. And he said unto him, What is thy name? And he said, Jacob. And he said, Thy name shall be called no more Jacob, but Israel: for as a prince hast thou power with God and with men, and hast prevailed. And Jacob asked him, and said, Tell me, I pray thee, thy name. And he said, Wherefore is it that thou dost ask after my name? And he blessed him there. And Jacob called the name of the place Peniel: for I have seen God face to face, and my life is preserved".

${ }^{59} \mathrm{Cf}$. Ex 3, 2: "And the angel of the Lord appeared unto him in a flame of fire out of the midst of a bush: and he looked, and, behold, the bush burned with fire, and the bush was not consumed"; Ex 19, 18: "And mount Sinai was altogether on a smoke, because the Lord descended upon it in fire: and the smoke thereof ascended as the smoke of a furnace, and the whole mount quaked greatly". 
the world. He reveals His will midst of the prophets and His Epiphany and allow people to know Him midst of his actions, because nobody can ever see God's face and then he can live by anyone live, as God told Moses: "And he said, thou canst not see my face: for there shall no man see me, and live" (Ex 33, 20).

In the New Testament the Father makes a manifest midst of the Second Person of the Holy Trinity, revealing His will and declares unequivocally, "He who has seen Me has seen the Father" (Jn 14, 9). Anyhow, the Son is the enhypostatic icon of the Father. At this point, the Psalmist's words put into practice: "The light of thy countenance O Lord, is signed upon us" (Ps 4, 7).

Isidore notes that God the Father was revealed to Jacob and fought with him. However, He did not reveal His name. In this way Isidore explains that the name of God is not under the law and beyond the law ${ }^{60}$. God appears Himself to mane people who live in God and God lives in them: "and it is no longer I who live, but Christ lives in me" (Gal 2, 20).

Isidore emphasizes that God didn't talk to righteous people midst writings of the Old Testament "to the olds" 61 , but He spoke to them directly, "by Himself, He finds the pure and unimpeded opinion to them without mediators' teaching" To document the above opinion, Isidore brings the facts about $\mathrm{Noah}^{63}$ and Abraham $^{64}$ as examples. In the first, God reveals Himself and advises him to build an ark, by which Noah and his family and all kinds of animals in pairs would be saved by the upcoming Cataclysm. After the flood of forty days, God concluded a covenant with Noah, giving the promise that He will never again destroy the creation of World with Cataclysm. On the other hand, with regard to Abraham, God talks to him and promises him that his descendants would become whatsoever in number the stars of the sky and grains of sand of the sea ${ }^{65}$, while $\mathrm{He}$ foretells the birth of his son Isaac from his decrepit wife Sarah ${ }^{66}$.

The Father revealed himself in an indirect way, midst the Cherubim, that were over the ark of the covenant, testament. The Cherubim, "Being the

\footnotetext{
${ }^{60}$ Cf. Isidorus Pelusiota, Epistula I 453 (Theodosio), PG 78, 432B (cf. Gen 30, 32).

${ }^{61}$ Idem, Epistula III 106 (Isidoro Diacono), PG 78, 812A.

${ }^{62}$ Ibidem.

${ }^{63}$ Cf. ibidem. Cf. Gen 7, 1: "And the Lord said to Noah, Take all your family and go into the
} ark, for you only in this generation have I seen to be upright".

${ }^{64}$ Cf. idem, Epistula III 106 (Isidoro Diacono), PG 78, 812A. Cf. Gen 12, 1-4: "Now the Lord said to Abram, Go out from your country and from your family and from your father's house, into the land to which I will be your guide. And I will make of thee a great nation, and I will bless thee, and make thy name great; and thou shalt be a blessing: And I will bless them that bless thee, and curse him that curseth thee: and in thee shall all families of the earth be blessed. So Abram departed, as the Lord had spoken unto him; and Lot went with him: and Abram was seventy and five years old when he departed out of Haran".

${ }^{65}$ Cf. idem, Epistula III 296 (Agatho Presbytero), PG 78, 972A (cf. Gen 15, 5; 16, 10).

${ }^{66}$ Cf. ibidem. Cf. Gen 17, 19: "And God said, Sarah thy wife shall bear thee a son indeed; and thou shalt call his name Isaac: and I will establish my covenant with him for an everlasting covenant, and with his seed after him". 
chariot ant the throne of God" ${ }^{67}$. They revealed Him for whom the Ark of the Covenant and the Temple of Solomon were constructed "He who has His seat on the winged ones (Cherubims), let His glory be seen"68. By this way, they proclaim that the God is inseparable and unformed. Further They emphasize that the God is the ruler and poet all and, simultaneously, "beyond any kind of nature and human contemplation" 69 . Finally, the God speaks to the Jewish people midst of Moses and the other prophets and thus He reveals His will every time ${ }^{70}$.

In the New Testament, the God Father, as He revealed Himself through Jesus Christ, is the beginning and the end of all Virtues: "Therefore you shall be perfect, just as your Father in heaven is perfect" ${ }^{\text {"11 }}$. Midst of the Holy Spirit, the Father will reveal His will to His apostles and He will recall all to them ${ }^{72}$.

Generally, the Pelousiote father points out that in the Old Testament the Father God reveals Himself to various people of the Israel with direct and indirect way. People like Noah, Abraham, Jacob and Moses had the opportunity to "Know" the God the Father who He is revealed. These people worked as the means midst of whose the plan of God for the salvation of man would be revealed to chosen people of Israel. The father, however, reveals Himself by an indirect way, through the words of the prophets, who were enlightened by the Holy Spirit. They seem His will. Finally, in the New Testament, the Father is revealed through the Son's Incarnation.

4. Epiphany - Revelation of the God Word. The Epiphany of the God Word directly related to the fleshless revelation, as the Word of God, and the incarnate one as Logos became man. In the Old Testament, God's Word is initially fleshless. In no way He presented as independent person and entity, but only He reveals Himself during His contact with the world, when He reveals His existence.

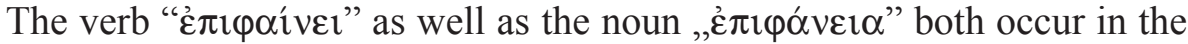
Greek New Testament. In 2 Timothy joyously declares:

"God, who has saved us and called us to a holy life-not because of anything we have done but because of his own purpose and grace. This grace was given us in Christ Jesus before the beginning of time, but it has now been

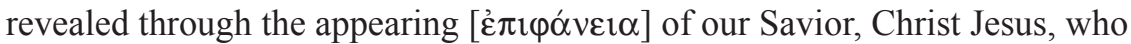

${ }^{67}$ Idem, Epistula IV 73 (Eusebio Episcopo), PG 78, 1133A.

${ }^{68}$ Ibidem (cf. Ps 80, 1).

${ }^{69}$ Ibidem.

${ }^{70}$ Cf. idem, Epistula IV 205 (Olympio Presbytero Scholastico), ed. M.P. Évieux, SCh 422, Paris 1997, 284, lines 64-67 (= PG 78, 1296C).

${ }^{71}$ Idem, Epistula III 95 (Isidoro Diacono), PG 78, 804B-C (cf. Mt 5, 48).

${ }^{72}$ Cf. ibidem, PG 78, 812B. Cf. Jn 14, 26: "But the Comforter, which is the Holy Ghost, whom the Father will send in my name, he shall teach you all things, and bring all things to your remembrance, whatsoever I have said unto you". 
has destroyed death and has brought life and immortality to light through the gospel" (2Tim 1, 8-10).

In the Old Testament, the Word of God does not only reveal the will of the Father but He shows His creative abilities. He creates the world visible and invisible and shapes man together with the other two Persons of the Trinity. Isidore underlines that Isaiah saw "incarnation" of Savior" ${ }^{73}$ In the New Testament, the pre-eternal Logos, consubstantial with the Father and the Holy Spirit, becomes perfect man and remains, at the same time, and perfect God. He incarnated in order to free people from the bondage of the original sin and to reunite man with God the Creator. By this way the incarnate Word of God reveals Himself throughout the world, calling people to repentance and moral perfection. So the human race could achieve their subjective salvation.

The Son appeared to the human race as man with hymns of victory celebration $^{74}$. Of course, Isidore means, the fact of Christ's birth in Bethlehem, in the course of which Angels were going up and down from the sky and were chanting "Glory to God in the highest, and on earth peace, good will toward men" (Lk 2, 14). By this way they were confirming this supernatural event to the simple and humble shepherds. They, with a pure heart and a sincere intention, accepted without any cunning and frankly this divine revelation.

The appearance of the Son to people, as one of them, was happened because of the charity of the Creator Father. By the theophany of Logos in the earth, the veil of Love was spread in the whole Creation ${ }^{75}$. As clean and living water of truth, the Lord blotted man, the image of God, from the dirt of sin, which marred the beauty of human nature. He gave, therefore, the ability to

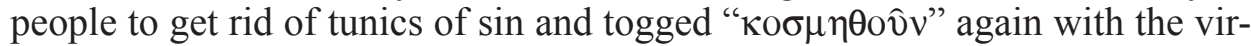
tues of their situation before the fall. So, when the King of Heaven appeared in the earth, He established doctrines, which would be a compass for people in order live an angelic lifestyle on earth ${ }^{76}$. Thus, God's revelation in history and His "incorporation- $\varepsilon v \sigma \omega \mu \alpha \alpha^{\prime} \omega \sigma \eta$ " into the existence of the fallen man, in other words His Incarnation, He alters the fallen man to a "new man".

Christ, however, revealed His divine glory by his Metamorphosis on Mount Thabor. There, He revealed to His reputable disciples the uncreated light of His glory. The latter will be fully revealed at the Second Coming of Christ on earth. At the same time, by the presence of Moses and Elijah, Christ affirmed his sovereignty over the living and the dead people, over the past, the present and the future ${ }^{77}$.

${ }^{73}$ Cf. idem, Epistula IV 154 (Anatolio Diacono), SCh 422, 356, lines 7-9 (= PG 78, 1240B).

Cf. Is 26,9 .

${ }^{74}$ Cf. idem, Epistula I 436 (Zosimo), PG 78, 421D.

${ }^{75}$ Cf. idem, Epistula IV 15 (Epimacho Lectori), SCh 454, 446, line 10 (= PG 78, 1064B).

${ }^{76}$ Cf. idem, Epistula IV 103 (Dionysio Scholastico), SCh 422, 486, lines 17-21 (= PG 78, 1104B-C).

${ }^{77}$ Cf. idem, Epistula I 239 (Alphio Presbytero), PG 78, 329B. Cf. Lk 9, 28-31: “And it came 
Generally, Isidore focuses the spotlight on the fact that, in the Old Testament, Logos is revealed, mainly through the making of creation and reveals His will to the righteous of the Old Testament. The fleshless Word reveals the Triune God and His will to Patriarchs, Prophets, Judges. In the New Testament, the Word manifested as a incarnated. He is who became from fleshless incarnated. As incarnated he would redeem the human leavens from the shackles of Satan and restore the broken relationship between God and man. By the illumination of the uncreated light of the divine glory, during His Transfiguration on Mount Thabor, Christ revealed that $\mathrm{He}$ is the only God and $\mathrm{He}$ has power to life and death.

5. Epiphany - Revelation of the Holy Spirit. The Holy Spirit reveals Himself to man from the time of creation of the universe until the end of the world. In his letters, Isidore of Pelusium notes that the Holy Spirit is manifested through oral and written revelation gradually and progressively. The progressive revelation of the triune Godhead, firstly of God Father, then of God Son and, later of God Holy Spirit, is a process of God's condescension to people's inability to understand the mystery of the Godhead.

In the Old Testament, as someone can see from the Psalms and prophets, there is a knowledge of the Divine Word and the Spirit of God. There is no knowledge of the Divine Word and the Divine Spirit as hypostasis. These two persons were considered as energies, because the world of the Old Testament was narrowly enclosed within the boundaries of one God. This point of view was provided in the sense not of the Christian monotheism, but of the sense

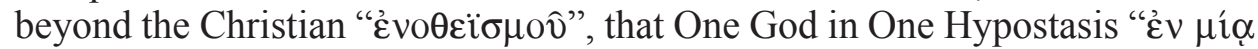
$i \pi 0 \sigma \tau \alpha \sigma \sigma \varepsilon \imath " 78$. In the Old Testament, which typically it is regarded as the first stage of the divine revelation, the reference to Holy Spirit's person and action was hidden ${ }^{79}$. The action of the Holy Spirit has no source outside of the divine nature of Spirit. Nor does He act independently of the Father and the Son. Among the three divine hypostases there is unity of volition and actions. The actions of the Spirit is uncreated and eternal, as the other persons' of the Holy Trinity actions.

Holy Isidore spoke in his letters about the Holy Spirit's theophany midst of his actions. He knew that the actions of the third hypostasis of the Triune God bestows at creation and rational beings, but they do not limited there. His

\footnotetext{
to pass about an eight days after these sayings, he took Peter and John and James, and went up into a mountain to pray. And as he prayed, the fashion of his countenance was altered, and his raiment was white and glistering. And, behold, there talked with him two men, which were Moses and Elias: Who appeared in glory, and spake of his decease which he should accomplish at Jerusalem". Also cf. Mt 17, 2-3; Mk 9, 3-4.

${ }^{78}$ Sophronius Sacharoph, Principles of orthodox asceticism, transl. in Russian and French text from monk Zacharia, Essex 1996, 111.

${ }^{79}$ Cf. Isidorus Pelusiota, Epistula II 143 (Paulo), PG 78, 589A.
} 
actions play an important role to Word's of God incarnation. In particular, in several letters of Isidore, he supports the doctrine of seedless Conception of Jesus Christ and notes that Holy Spirit played an important role in the incarnation of the divine Logos: "By Holy Spirit there is Word as infant enfleshed ( $\sigma \varepsilon \sigma \alpha \rho \kappa о \mu \varepsilon ́ v o \varsigma)$ in Virgin's womb" $"$. He expresses the view that it is difficult to be understood the way that Theotokos conceived. This is characterized as "god-like [...] and not conceived in human's mind" ${ }^{\text {. }}$. The Spirit is the One which, by attending the Baptism of the Lord confirms the ó $\mu$ oov $\sigma$ ió $\tau \tau \alpha$ of the Son with the Spirit and the Father. He provided the testimony of the divinity of Incarnate Word ${ }^{82}$.

Also, the fact of God's speaking through the fire of the fuming Mount Sinai (cf. Ex 19, 19) is paralleled by Isidore with the descent of the Holy Spirit to the Apostles (Acts 2, 1-4) on the day of Pentecost. All of these examples indicates that everything happened "in order to be known that God is one and the same into both Testaments, although the second one has many differences to the first" $"$. By this parallelism Isidore achieved to present that both Testaments have common base the revelation of God and His plan of salvation of mankind, and, moreover, Isidore makes an evidence that the Holy Spirit is God, too.

The Holy Spirit, however, "the heavenly force", as Isidore taught, has "active presentation" after Christ's Ascension. By this way, Christ's disciple would have companion and assistant in the preaching of the Gospel, that "He always memorises everything to you" $\$ 4$. Characteristically, their master had promised to them that "the divine Spirit would descend upon the twelfth Apostles the tenth day after Christ's Ascension, and the whole fifty days between after His Resurrection day, as Lord announced a few days after his promise that He would be transferred to heaven" 85 .

The day of Pentecost is the fullness of time for the mission of the Holy Spirit to the Apostles. They will cultivate the souls of all people, by the teaching and the preaching of the Word Incarnate. By this way, people will have the opportunity perform spiritual fruits. The revelation of the Spirit to students on the day of Pentecost appeared unto them "cloven tongues" 86 like as of fire, and it sat upon each of them. The tongues are not from fire but they look like fire, but it looks like fire. The "like" helps us to realize that the Spirit is beyond aesthetic perception, because $\mathrm{He}$ is neither fire nor wind, nor dove, nor anything that has a material substance. The fire, after all, is an often way for God's revelation. The result of the revelation of Holy Spirit on Pentecost is the same

\footnotetext{
${ }^{80}$ Idem, Epistula I 18 (Hermino Comiti), PG 78, 193A (cf. Mt 1, 20).

${ }^{81}$ Ibidem.

${ }^{82}$ Cf. idem, Epistula I 67 (Timotheo Lectori), PG 78, 228A.

${ }^{83}$ Idem, Epistula I 494 (Timotheo Lectori), PG 78, 452A.

${ }^{84}$ Idem, Epistula III 106 (Isidoro Diacono), PG 78, 812B (cf. Jn 14, 2-6).

${ }^{85}$ Idem, Epistula I 400 (Archiae), PG 78, 453B-C (cf. Acts 2, 4-8).

${ }^{86}$ Idem, Epistula IV 66 (Hermino Comiti), PG 78, 1124A (cf. Acts 2, 3).
} 
Holy Spirit like fire Who continues to burn and brighten people's souls. Their lighting is the only way for the conquest of their heavenly salvation.

On the day of Pentecost, therefore, the Holy Spirit illuminates and teaches $(\delta \alpha \delta \circ v \chi \varepsilon \hat{\imath})$ Lord's disciples, in order to understand fully what they were taught by Christ and to preach them to all over the world. By this way, They became brighten lighthouses. By the light of the saviour preaching, they would chases away the darkness of the devil's delusion. On this day, Pentecost, the whole action of the Spirit will be granted. This action brings the kingdom of God to the hearts of people of all nations. The Holy Spirit, as Alexandrian Father highlighted features, "by fire He was given to Apostles" ${ }^{\text {" } 77}$. Isidore stresses emphatically that the Spirit appeared unto the Disciples of Christ on the day of Pentecost. By this teaching, he refutes Montanus. The latter taught that the Spirit had not descended to the Disciples of Christ at Pentecost, but later only to him. He argues that he claimed this theophany, without doing anything important, but because he recognized his dissolute life in public ${ }^{88}$.

Isidore likened the Spirit's revelation like a fire from an oil lamp, from which many candles are illuminated. The ardency, that comes from the Spirit's fire, gives impetus to every faithful man to look to the sky and break the shackles of sin which keeps him tethered to earth. The Spirit permutes man, He redeems him, He takes him to deification. We must not, of course, forget that the Holy Spirit acts in the Church because of Christ's redemption. This faith is a necessary and a fundamental prerequisite for the intake of human being to the new creation and base of the creation by the believers in the Holy Spirit. The believers should accept continually the divine Spirit's donation in order to be rendered Spiritual ( $\pi v \varepsilon v \mu \alpha \tau$ có́por). Of course, we must not forget that the grace of the Spirit is not a permanent and inalienable possession of the faithful men and women. In contrast, the energy and sanctification of the Spirit are solely charismatic gifts of God, which always are reallocated to the believers, but they remain eternally in Church.

Isidore, however, returns to $\varepsilon \pi \iota \varphi \omega \tau i \sigma \varepsilon \omega \varsigma$ fact, to the descent of the Spirit to the Lord's disciples in the form of fire, because by this form, God Father had spoken to Moses ${ }^{89}$, in order to show the consubstantiality of the Spirit with God Father. The outpouring of the Holy Spirit to the apostles made them look drunk in the eyes of those who knew them, according to the testimony of Luke in the Acts ${ }^{90}$. The Apostles, that moment, felt the sweetness of the grace of the Spirit. For this reason they felt a sober drunkenness, the living of the true life, the deification of man, the communion with God. The same Holy Spirit was the instrument that turned them inside, empowered them spiritually and enabled them from simple fishermen in order to become preachers of the

\footnotetext{
${ }^{87}$ Idem, Epistula I 494 (Timotheo Lectori), PG 78, 453A.

${ }^{88}$ Cf. idem, Epistula I 243 (Hermino Comiti), PG 78, 332A.

${ }^{89}$ Cf. idem, Epistula I 494 (Timotheo Lectori), PG 78, 453A (cf. Ex 24, 17).

${ }^{90}$ Cf. idem, Epistula I 168 (Zoilo Presbytero), PG 78, 293B (cf. Acts 2, 13).
} 
Gospel to all mankind. And the communion with God begins - for everyone of us - with the sacrament of baptism.

The Holy father generally characterized the Divine as a fire and, in particular, the Holy Spirit. This can be justified because Isidore remains faith in the Holy Bible, which often bear witness that the Divine reveals to man by the image of fire, like in the revelation of God to Moses through the burning bush (Ex $24,17)$, as it was mentioned before. Then, a conclusion can be drawn that, as fire purifies everything that gets in her way, so the Holy Spirit sanctifies a man and turns him from burden of the earth to citizen of the kingdom of God. The Spirit removes the rust of sin, like fire exempts iron from the rust. The fire burns the waste, but it purifies the gold. Another characteristic feature of the fire is its move upwards, towards the sky. For this reason, the fire is one of the most appropriate types, in order the Third Person of the Holy Trinity to make His presence felt in the world. His main concern is to lead man upwards, to make him equal to God. At this point, Holy Isidore might imply that, as the Holy Spirit appeared in the form of fire at Pentecost, so the preaching of the Apostles, resembles fire, which spread to the world, to cleanse from sin and to transform it.

The Holy Spirit is revealed through the Scriptures. The research of the Divine Scriptures, "it has as message the precise knowledge of God"91 and reveals "the will of the Spirit" 92 . The Spirit "searches all things, even the depths of God" "93, He knows the most accurate knowledge of God with the Father and the Holy Spirit, and He declare it" 94 , as He is Himself one of the three Person of the Holy Trinity. The above passage of the first epistle to Corinthians is paralleled to the one of the Romans, which notes "He who searches our hearts" 95 , in order to show the consubstantiality of the Spirit to the Father. Isidore exports the conclusion that midst of the Spirit believers are enabled to acquire "precise attention" for the Father and for the Holy Spirit Himself ${ }^{96}$. From this conclusion, Isidore does not exclude the Son from having the accurate knowledge for the Triune God. Neither does he leave the slightest heretic suspicion. The latter would happen, if there was the use of the adverb "only" in the clause, which refers to the possession of the perfect knowledge of the Father and the Spirit.

$* * *$

The holy Isidore supports the progressive revelation of the Triune God, which begins with the revelation of God Father, in the Old Testament, it continues with the revelation of His incarnate in the New Testament, and finally,

\footnotetext{
${ }^{91}$ Idem, Epistula III 92 (Ophelio Grammatico), PG 78, 796D.

${ }^{92}$ Ibidem, PG 78, 796D - 797A.

${ }^{93}$ Ibidem, PG 78, 797A (cf. 1Cor 2, 10).

${ }^{94}$ Ibidem.

${ }^{95}$ Ibidem (cf. Rom 8, 27).

${ }^{96}$ Cf. ibidem.
} 
after the day of Pentecost by the Holy Spirit's relevance. In these three periods of human history, the Holy Spirit always plays an active and important role. He creates the first man along with the other two persons of the Triune God. He is revealed "mist of clouds" in the Old Testament. He makes His revelation into the events of Christ's arrest, into Incarnate Word and the baptism. Still, it is the "finger" with which Christ cast out demons. Finally, after the Ascension, the Lord becomes the driver and the assistant in order to preach this divine word everywhere of the world and prepare people to enter the Kingdom of Heaven.

Pelousiote Father, referring to the dynamic revelation of the Spirit in the Historical "mainstream", he combated all falsehoods of Montanus and heretical beliefs in the letters of falsehoods Montanus. And other heretical beliefs

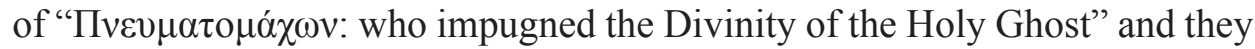
had survived to his day. Although, as we noted above into letters of Isidore, he did not deal with the dogmatic teaching of the Church in detail. However, Isidore seems, to know very well about the issues and doctrines. He trackers on theology of earlier church fathers, who left an indelible mark on the formulation of doctrine.

Isidore agrees that the knowledge about God transcends to every human's thought and word and it (knowledge) is based entirely on the fact of God's revelation, which can be understood only through the grace of the Holy Spirit. He accounts for the people to know that God exists and not to seek "what by nature is" our God. Consequently, Isidore makes some effort to explain, that if the teaching of the Church for the Triune God, on Christ and on the Holy Spirit is based solely on logic, it is doomed to fail but to lure them into the deception of heresy, together with those who share their views. For this reason, the heretics, although they read the Bible, they do not let themselves be filled with the true light of the Third Person of the Trinity, so does not this lead to good faith, thus he will be cut off from the Body of Christ the church. The correct faith will help the knowledge of God, since the first is the key to enter the mystery of the Holy Trinity.

Isidore converged on the view that knowledge of God cannot be achieved by relying solely on finite human intellection, without even the assistance is provided by the same Triune God and phase in history. Otherwise, the Spirit will reveal the uncreated truth by shadow. Only has Christ the ability, as good sewer to sow in the hearts of those who are worthy, as the disciples and Apostles, the exact knowledge of the doctrines and to desire any good thing, such as giving the opportunity to every man who feels thirsty for the divine truth. Consequently, the Knowledge for the Christ Christognosia is closely associated with the Triadognosia and it should provide the knowledge of the Divine Incarnation of the Logos. The latter is the revelation of the Trinity in Christ and Christ is revealed as one of the Trinity. 
WIEDZA O TRÓJJEDYNYM BOGU WEDŁUG IZYDORA Z PELUZJUM

\section{(Streszczenie)}

Bóg jest niepojęty i ten fakt musi być zaakceptowany przez każdy umysł ludzki. Możliwe jest jednak poznanie Go poprzez Jego dzieła, ale do tego niezbędny jest wolny od grzechu umysł i posiadanie takich cnót, jak mądrość, sprawiedliwość, miłość i wiara. Tylko wtedy Bóg będzie mógł „mieszkać” i „przechadzać się” w nas, i da nam szansę spotkania Go. Izydor z Peluzjum porównuje prawdziwą wiedzę o Bogu do „wina”, co wynika z obecności wcielonego Boga Logosu na Ziemi i objawienia jego nauczania. Ponieważ Pan opisuje siebie jako winorośl, pewność wiedzy o Nim jest nazywana „winem”. Bóg jest Jeden i Trójjedyny. Dowód ten pochodzi z Biblii. Peluzjota wyjaśnia, że liczba pojedyncza w Biblii, która jest używana odnośnie Boga, odnosi się do wszystkich trzech Osób Bożych, które są współistotne, liczba mnoga zaś odnosi się do hipostazy Boga w Trójcy Jedynego. Izydor podkreśla, że znajomość Boga wymaga wielkiej dojrzałości duchowej i mądrości. Wiara ludzi we wcielone Słowo Boże objawia się pośród Boga w Trójcy Jedynego i pomaga racjonalnemu stworzeniu wspiąc się do rzeczywistości niebieskiej i „rozmawiać” z Bogiem. Osoba przyodziana godłem prawdziwej wiedzy o Bogu, danej jej przez światło Ducha Świętego, czyni ją zdolną do walki z tymi, którzy nadużywają prawd doktryny Kościoła.

Key words: Isidore of Pelusium, Triune God, Christus, knowledge of God,

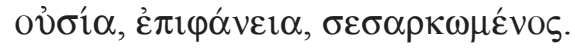

Słowa kluczowe: Izydor z Peluzjum, Trójjedyny Bóg, Chrystus, wiedza

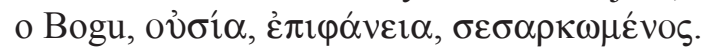

